\title{
Aksjologiczne podstawy konstytucji
}

DOI: $10.35757 /$ CIV.2007.10.01

Niniejszy tekst ${ }^{1}$ składa się $z$ dwóch części. W pierwszej rekonstruuję przesłanki aksjologiczne, na których opiera się projekt nowoczesnego państwa konstytucyjnego, wskazując jego założenia, ich konsekwencje instytucjonalne oraz najważniejsze obszary napięć, które pojawiają się w jego ramach. W drugiej wskazuję najistotniejsze dylematy, które należałoby rozważyć i świadomie rozstrzygnąć, podejmując się dzieła zaprojektowania konstytucji w konkretnej sytuacji Polski Anno Domini 2007.

Każda wspólnota międzyludzka posiada coś, co ją integruje, wyróżnia od innych wspólnot i określa jej tożsamość. Sa to - mówiąc najprościej - wspólnie wyznawane wartości łączące tych wszystkich, którzy do wspólnoty należą. Stawiając pytanie o przekaz aksjologiczny zawarty w konstytucji, odnosimy się do szczególnej wspólnoty - do wspólnoty politycznej, w jej najbardziej rozwiniętej, współczesnej formie, którą nazywamy państwem konstytucyjnym. U podstaw takiego państwa oraz jego struktury insty-

Zbigniew Stawrowski - filozof polityki, doktor habilitowany, pracuje w Instytucie Studiów Politycznych Polskiej Akademii Nauk oraz wykłada w Collegium Civitas w Warszawie. Jest dyrektorem Instytutu Myśli Józefa Tischnera w Krakowie.

1 Powstał on na kanwie dyskusji prowadzonych w pierwszym półroczu 2007 roku w ramach komisji ds. aksjologii konstytucji powołanej przez Rzecznika Praw Obywatelskich. 
tucjonalnoprawnej zapisanej $\mathrm{w}$ ustawie zasadniczej leżą pewne fundamentalne wartości, stopniowo uświadamiane, a następnie powszechnie zaakceptowane w ciagu długiego procesu dziejowego, który dokonał się w naszym kręgu kulturowym. W tym sensie już sama forma państwa konstytucyjnego - abstrahując jeszcze od wartości wyrażonych expressis verbis $\mathrm{w}$ tekście konstytucji - niesie w sobie określoną propozycję aksjologiczną, określona wizję człowieka i międzyludzkiej wspólnoty.

Należy przede wszystkim podkreślić, że państwo konstytucyjne jest projektem, wypracowanym w teoretycznych debatach i weryfikowanym w praktyce politycznej, który stanowi modyfikację i udoskonalenie przełomowego wynalazku czasów nowożytnych - nowoczesnego państwa wolności. Aby odsłonić wartości, na których ufundowane zostało i które urzeczywistnia państwo konstytucyjne, musimy sięgnać do samych początków - nie tylko do nowoczesnego państwa sprzed epoki konstytucji, ale do państwa jako takiego.

1. Pierwszą i podstawowa wartościa dla każdej bez wyjątku wspólnoty politycznej - czy to będzie wspólnota plemienna, antyczna polis, współczesne państwo, czy jakikolwiek inny organizm polityczny - jest samo jej istnienie ${ }^{2}$. Aby tę wartość skutecznie realizować, niezbędna jest instytucja wladzy. Niezbędna nie tylko $z$ tego względu, że głównym zadaniem władzy jest właśnie ochrona wspólnotowego bytu, ale także $\mathrm{w}$ tym sensie, iż bez wyposażonej $\mathrm{w}$ odpowiednią moc władzy zwierzchniej wspólnota polityczna po prostu nie istnieje ${ }^{3}$. Władza jako taka, będąc zarówno nośnikiem, jak i strażnikiem owej podstawowej wartości, jest więc w swej istocie zasadniczo „dobra”, niezależnie od wszelkich nadużyć popełnianych przez sprawujących ją ludzi. Dobra „w sobie”

\footnotetext{
2 Narzuca się tu analogia $z$ jednostką, dla której jej istnienie jest wartością może nie zawsze najważniejsza, ale $z$ pewnością podstawowa, stanowiącą konieczny warunek osiagania wszelkich innych wartości.

3 „Państwo jest taką wspólnota ludzką, która w obrębie określonego terytorium rości sobie (z powodzeniem) prawo monopolu na wywieranie prawomocnej przemocy fizycznej”, M. Weber: Polityka jako zawód i powołanie, przekład A. Kopacki, P. Dybel, Społeczny Instytut Wydawniczy Znak, Fundacja im. Stefana Batorego, Kraków - Warszawa 1998, s. 56.
} 
władza może oczywiście działać lepiej lub gorzej, może wypełniać swoją funkcję dobrze lub źle. W tym węższym sensie „dobra” władza to władza skuteczna, taka, która potrafi skutecznie chronić swoja wspólnotę. Tak rozumiana skuteczność stanowi pierwsze kryterium, wedle którego należy oceniać działania władzy w każdym organizmie państwowym.

Władza pełni przede wszystkim funkcje jednoczącą. Stanowi ośrodek, który integruje wspólnotę, zapewnia jedność jej działań, określa ich kierunek i hierarchię wyznaczanych celów. Żadna społeczność nie może się obejść bez kogoś, kto nią rządzi, albowiem „wszędzie tam, gdzie jest wielość, musi być czynnik rządzący”4. W sytuacji, gdy w ewidentny sposób brakuje jedności działania, trudno już mówić o jednej wspólnocie politycznej. Mamy wtedy raczej do czynienia $z$ wieloma rywalizujacymi ze soba ośrodkami władzy, a tym samym $z$ wieloma potencjalnymi organizmami politycznymi. Jedność wspólnoty państwowej, w tym także jedność i niepodzielność samej władzy, to wartość, która w gruncie rzeczy mieści się $\mathrm{w}$ pojęciu istnienia państwa i stanowi tylko jego dookreślenie. $Z$ tego względu rozróżnienie i wydzielenie w ramach jednej instytucji władzy rozmaitych władz (na przykład wykonawczej, ustawodawczej czy sądowniczej) ma znaczenie funkcjonalne, a nie realne. Gdyby stały się one faktycznie odrębnymi ośrodkami władzy, państwo jako jedność polityczna ległoby w gruzach ${ }^{5}$.

\footnotetext{
4 Św. Tomasz: O władzy, w: idem: Dzieła wybrane, Wydawnictwo „W drodze”, przekład J. Salij, Poznań 1984, s. 135.

${ }_{5}$ Aż do XVII wieku w refleksji politycznej panowała organiczna wizja państwa. To, co dziś nazywamy różnymi władzami, postrzegane było jako rozmaite organy czy też funkcje jednej władzy zwierzchniej. Dysponowała ona zarówno władzą nadawania praw, jak i ich egzekucji, a także stanowiła ostateczna instancję wymiaru sprawiedliwości. Nowożytna, liberalna teoria podziału i wzajemnego powstrzymywania władz pojawiła się natomiast dopiero wówczas, gdy - abstrahując od obecności państwa - za punkt wyjścia przyjęto jednostkę, by następnie jej korzyścia uzasadniać potrzebę powołania instytucji państwowych. To jednostka, a nie istnienie wspólnoty, okazuje się w takim teoretycznym modelu podstawowym celem państwa, zaś wszystkie władze państwowe mają pełnić wobec jednostki i jej wolności funkcje służebne. A skoro władze te - jako kumulacja siły - mogły stanowić dla jednostek również źródło zagrożenia, zrodził się pomysł, by owe władze sobie przeciwstawić i tym samym osłabić, właśnie w celu zabezpieczenia indywidualnej wolności. Problem w tym, że realizacja tego pomysłu pociaga za soba zarazem osłabienie wypełniania przez państwo jego właściwych zadan, to znaczy właśnie ochrony bezpieczeństwa i wolności jednostek.
} 
Konkretna wspólnota państwowa, której bytu i jedności ma skutecznie bronić władza zwierzchnia, istnieje zawsze jako wspólnota o określonej tożsamości etycznej. Każda rzeczywista wspólnota ma swoisty normatywny porządek zachowań uznawanych w jej obrębie za właściwe. Ten właśnie porządek odzwierciedla jej system wartości (etos), określa jej swoiste imię etyczne. Władza, chroniąc swoja wspólnotę, musi równocześnie skutecznie troszczyć się o jej tożsamość etyczną. Inaczej wspólnota podzieliłaby się wewnętrznie albo przestałaby być soba - przestałaby istnieć jako ta właśnie jedna wspólnota etyczna. Etyczny ład wspólnoty, wyrażony w postaci pisanych i niepisanych praw, stanowi dla jej członków jedyna miarę oceny zachowań; kto postępuje zgodnie $z$ tym porządkiem, postępuje słusznie i sprawiedliwie. Sprawiedliwość to synonim etycznego porzadku. Władza, strzegac tego porządku, oddaje każdemu to, co mu się słusznie należy - stosownie do jego czynów i według zasad obowiązujących w tej wspólnocie. Działanie władzy „niczym innym nie jest [...] jak wprowadzaniem w życie zasad sprawiedliwości”ø. Im lepiej i skuteczniej władza to czyni, tym bardziej jest sprawiedliwa.

Każda wspólnota państwowa - począwszy od tych najbardziej archaicznych po współczesne - zawsze zawiera w sobie oba wymienione wyżej elementy ${ }^{7}$ określony porządek etyczny, wyznaczajacy swoisty rytm życia społeczności i dostarczający jej członkom miary tego, co słuszne i sprawiedliwe, oraz władzę, która stoi na straży wspólnoty - jej fizycznego przetrwania i etycznej tożsamości. Mamy

\footnotetext{
6 Platon: Prawa [757c].

7 Warto na marginesie zauważyć, że między władza a porządkiem, który ma ona chronić i któremu ma służyć, istnieje stan nieustannego napięcia. Władza jest pojęciem paradoksalnym, zawiera w sobie zarówno element zwierzchności, jak i służebności. W refleksji filozoficznej nad porządkiem politycznym napięcie to wyrażano w odwiecznym dylemacie: jak spowodować, by władca, będący gwarantem obowiązującego porządku, sam nie ulegał pokusie łamania tego porządku. Próba odpowiedzi były rozważania myślicieli starożytnych i średniowiecznych o władzy sprawiedliwej (to znaczy służebnej wobec swej wspólnoty), ich propozycje zapewnienia ładu etycznego poprzez odpowiednią edukację władcy, przez poddanie go władzy „strażnika wewnętrznego" - sumienia i rozumu, zaś w czasach nowożytnych rozmaite teorie podziału i wzajemnego ograniczenia władzy. Napięcie to nabiera szczególnego charakteru w momencie zwycięstwa idei demokratycznej, skoncentrowanej na władzy jako takiej, dla której pojęcie służby jest niezrozumiałe.
} 
tym samym dwa uzupełniające się punkty widzenia, pozwalające ocenić konkretną organizację państwa.

$Z$ jednej strony istnieje szczególna „aksjologia” (a raczej pragmatyka) sprawowania władzy jako takiej, której podstawową miara jest skuteczność. $Z$ tej perspektywy możemy sensownie porównywać funkcjonujace $\mathrm{w}$ danej epoce konkurencyjne rozwiąania instytucjonalne (na przykład antyczną demokrację i monarchię, liberum veto i zasadę większości, wojsko zaciężne i pospolite ruszenie, system prezydencki i system rządów parlamentarnych) oraz oceniać je jako te, które osłabiają lub wzmacniaja jedność działania i skuteczność władzy państwowej. Ta pragmatyczna perspektywa musi zostać uwzględniona również wtedy, gdy przystępujemy do oceny czy projektowania konkretnej konstytucji. Dobrze zorganizowany system instytucji władzy państwowej to przede wszystkim taki, który działa skutecznie.

$Z$ drugiej strony podstawa aksjologicznej oceny organizmu państwowego musi być również konkretna treść leżącego u jego podstaw etycznego ładu. Na tle jednolitych etycznie organizmów państwowych różnych epok ${ }^{8}$ przełomowy charakter nowożytnego projektu państwa polega na tym, że u jego podstaw znalazły się wartości uniwersalne ${ }^{9}$. Władza ma tu za zadanie chronić nie tyle specyficzny sposób życia wspólnoty w całym jego bogactwie etycznym, ile jedynie te wartości, które przysługują człowiekowi jako takiemu - jako wolnej, rozumnej jednostce. Opis, jak doszło do jego powstania nowoczesnego modelu państwa, możemy tutaj pominać ${ }^{10}$. Przedstawmy natomiast jego fundament aksjologiczny i wynikające $z$ niego konsekwencje instytucjonalne.

\footnotetext{
8 Takie jednolite etycznie organizmy polityczne występuja także współcześnie (na przykład Arabia Saudyjska czy inne państwa islamskie).

9 Mówiąc językiem Hegla, etosem, etycznością (Sittlichkeit) państwa nowożytnego okazuje się moralność (Moralität).

${ }^{10} \mathrm{Na}$ temat historyczno-politycznego kontekstu kształtowania się takiego państwa w okresie szesnastowiecznych i siedemnastowiecznych wojen religijnych oraz uznania pacyfikacyjnej funkcji władzy za nadrzędna por. np. E.W. Böckenförde: Wolność, państwo, Kościót, przekład P. Kaczorowski, Społeczny Instytut Wydawniczy Znak, Kraków 1994, s. 100-117. Nurt refleksji filozoficznej, w ramach którego rozwijane były teoretyczne zreby nowoczesnego modelu państwowości, znaczony takimi nazwiskami jak przede wszystkim Thomas Hobbes czy John Locke, swoja najbardziej dojrzałą formę znalazł w koncepcji Immanuela Kanta.
} 
2. Istotę nowoczesnego państwa prawa - państwa w sensie ścisłym ${ }^{11}$, opartego na zasadzie poszanowania moralnej autonomii jednostki - można wyrazić następująco: o ile każda bez wyjątku wspólnota polityczna musi posiadać ośrodek władzy, który gwarantuje jedność jej działań, chroni jej istnienie przed zewnętrznym zagrożeniem i utrzymuje obowiązujący we wspólnocie ład etyczny, o tyle państwo jako stan bezpieczeństwa prawnego pojawia się wówczas, gdy władza, zaprowadzając wewnętrzny pokój i porządek, czyni to w imię sprawiedliwych zasad, które każdemu pełnoprawnemu członkowi wspólnoty oddaja to, na co naprawdę zasługuje jako istota rozumna, to znaczy traktuja go jako osobę wolna, samodzielna i odpowiedzialna.

Podstawowym aksjomatem perspektywy moralnej jest postrzeganie każdego człowieka jako istoty, która ma absolutną wartość - godność, i która należy traktować „zawsze zarazem jako cel, nigdy tylko jako środek"12. Opierając się na takim imperatywie, można wyprowadzić rozumny kształt porządku politycznego, w którym jednostki - nawet te, które nie potrafia lub nie chca postępować moralnie - sa poddane moralnie słusznym, to znaczy szanujacym ich godność, zewnętrznym regulacjom. Całość owych regulacji tworzy racjonalna strukturę: to, co nazywamy właśnie państwem prawa - stanem publicznie uznanych oraz gwarantowanych moca władzy państwowej słusznych uprawnień, zapewniającym wszystkim bez wyjątku jednostkom (jeśli trzeba, również za pomoca przymusu) bezpieczne i sprawiedliwe korzystanie $z$ ich wolności.

Państwo prawa stoi na straży i gwarantuje przestrzeganie następujacych zasad:

\footnotetext{
${ }^{11}$ Polskie słowo „państwo” jest niestety mylące i w żaden sposób nie oddaje swoistości projektu politycznego, z którym mamy tu do czynienia. Państwo (łac. dominium) znaczy bowiem dosłownie: to, co należy do jakiegoś pana (władcy). Natomiast istotny sens przełomu moralnego i politycznego, który dokonał się w czasach nowożytnych, zawiera się w słowie lo stato, użytym po raz pierwszy przez Machiavellego, a następnie przejętym przez inne języki europejskie (ang. state, niem. der Staat, fr. l'état). Tak rozumiane panstwo to wprowadzony świadomym aktem woli stan - bezpieczna przestrzeń działania, w której wszyscy członkowie wspólnoty moga się cieszyć równa wolnością; to, jak pisał Kant: rechtlicher Zustand - stan publicznie zagwarantowanych słusznych uprawnień każdego człowieka.

12 Por. I. Kant: Uzasadnienie metafizyki moralności [IV 433].
} 
- poszanowania nienaruszalności przestrzeni prywatnej, to znaczy życia, nienaruszalności cielesnej, własności prywatnej, a także prywatności rodziny;

- swobody działania w przestrzeni publicznej ograniczonej jedynie taka samą swoboda innych jednostek (lub społeczności).

Zasady te, rozmaicie formułowane i konkretyzowane, stanowia treść powstających od końca XVIII wieku kart praw człowieka i obywatela. Można jednak powiedzieć więcej: żadne „prawo”, którego nie da się przedstawić jako rozwinięcia i uszczegółowienia jednej $z$ owych dwóch zasad, nie zasługuje $-z$ punktu widzenia logiki tak pojętego państwa - na to, by wpisać je do katalogu praw podstawowych.

Główną rolę w państwie prawa odgrywa instytucja wymiaru sprawiedliwości, która - kierując się rozumnym osądem i rozumnymi zasadami - rozstrzyga konflikty, wyrokuje o przestępstwach, wyznacza sprawiedliwe kary i dzięki temu oferuje organom władzy właściwa podstawę przywracania naruszonego porządku. W ten sposób państwo prawa tworzy i chroni przestrzeń, w której bez większych napięć i konfliktów moga przebywać obok siebie ludzie oraz wspólnoty tak radykalnie różniące się między soba, że $\mathrm{w}$ innym organizmie politycznym zakończyłoby się to natychmiast ich wyniszczajaca walką. Wszyscy uzyskuja w takim państwie jednakowa ochronę prawną i mogą się cieszyć niewątpliwym, wspólnym dla wszystkich dobrem: sprawiedliwością, bezpieczeństwem i pokojem.

Ten spójny model państwowości nie zawierał początkowo pewnych elementów, które dziś w potocznym mniemaniu przyjmuje się za oczywiste. Po pierwsze, tak rozumiane państwo prawa to państwo ograniczone $\mathrm{w}$ swych funkcjach do minimum. Jego celem - jako państwa ufundowanego na wolności - nie jest zapewnianie ludziom szczęścia i pomyślności, lecz wyłącznie gwarantowanie im warunków elementarnego bezpieczeństwa, by mogli w pokoju - samodzielnie bądź w ramach rozlicznych stowarzyszeń i wspólnot - realizować swój pomysł na dobre życie. W ramach tych założeń 
instytucje tak zwanego państwa socjalnego, zajętego troską o dobrobyt swoich obywateli, które wypełniają ogromną część współczesnych organizmów państwowych, nie znalazłyby uzasadnienia racjonalnego i moralnego ${ }^{13}$.

Nie znaczy to jednak, że ważkie pytanie, co zrobić z ludźmi, którzy nie potrafia w pełni korzystać $z$ bezpiecznej przestrzeni wolności, lecz potrzebują wsparcia, może zostać zlekceważone. Wydaje się, że istnieje możliwość zmierzenia się $z$ tym problemem przy zachowaniu podstawowych założeń państwa wolności, a jednocześnie uniknięciu pułapki państwa socjalnego. Drogę ku temu otwiera uznanie solidarności za istotna wartość, która jednak ma być realizowana nie tyle bezpośrednio przez państwo, ile raczej - jako spontaniczna solidarność międzyludzka - szanowana i wspierana przez jego instytucje. Państwo powinno interweniować tylko w sytuacjach szczególnych, nagłych i jednorazowych, oraz wymagających takiej mobilizacji środków, która tylko ono może skutecznie przeprowadzić. Obowiąuje je jednak zasada pomocniczości - interwencje państwa, poza właściwa mu sferą gwarantowania bezpieczeństwa i sprawiedliwości, muszą być czymś wyjątkowym i ostatecznym.

Po drugie, państwo prawa poczatkowo wcale nie było pomyślane jako państwo o ustroju demokratycznym. Narodziło się ono $\mathrm{w}$ epoce, gdy istnienie monarchii jako władzy zwierzchniej było oczywistym faktem. Najważniejsze było to, aby władca sprawował swe rzady sprawiedliwie, by uznał nowy porzadek aksjologiczny oparty na poszanowaniu podstawowych praw jego poddanych oraz aby sam uczynił się ich gwarantem. Natomiast idea demokratyczna, która $z$ pełna moca pojawiła się wraz z rewolucja we Francji, zdemaskowała suwerenną władzę monarchy jako „wieczną zbrodnię" (Saint-Just) i na jej miejsce postawiła zwierzchność ludu. W wieku XX demokracja stopniowo stopiła się $z$ państwem prawa w jedną, niemal nierozróżnialną całość. Mogło do tego dojść, po-

\footnotetext{
${ }^{13}$ Por. I. Kant: O porzekadle: to może być słuszne $w$ teorii, ale nic nie jest warte $w$ praktyce [VIII
} 291, 302]. 
nieważ za uzasadnieniem prawomocności demokracji stała również idea autonomii jednostki, interpretowana jednak w taki sposób, że podstawowym prawem człowieka okazywało się nie tyle osobiste bezpieczeństwo i swoboda działania, ile prawo do uczestnictwa w suwerennej władzy. Obie idee - „państwa prawa” i „demokracji” - choć w ramach "demokratycznego państwa prawa” pozostaja w pozornej symbiozie, w gruncie rzeczy - właśnie ze względu na inne rozumienie tego, kim jest człowiek i na czym polega jego wolność ${ }^{14}$ - znajduja się $\mathrm{w}$ stanie stałego napięcia czy wręcz walki. W długiej perspektywie sa one nie do pogodzenia, a rozpowszechnienie się postaw demokratycznych oznacza stopniowa erozję etycznych fundamentów państwa prawa.

3. Pierwsze konstytucje, wprowadzając porzadek polityczny oparty na zasadach państwa prawa, nie łaczyły ich - poza przypadkiem Francji $-z$ idea demokracji. Co więcej, idea państwa konstytucyjnego była pomyślana jako polemiczna wobec wszelkiej władzy o skłonnościach absolutystycznych: zarówno monarszej, jak i demokratycznej ${ }^{15}$. W przypadku dziewiętnastowiecznych europejskich konstytucji oktrojowanych, które swoim poddanym nadawał monarcha, oznaczały one akt obustronnego zobowiazania prawem, a tym samym ograniczenie zakresu zwierzchniej władzy, uznanie jej odpowiedzialności oraz ustanowienie prawnych gwarancji dla wolności obywateli. W krajach, w których - tak jak w przypadku Stanów Zjednoczonych Ameryki - konstytucja faktycznie konstytuowała nowe państwo, a nie tylko reformowała dotychczasowy organizm polityczny, była ona nie tylko czynnikiem ograniczającym władzę, ale także czymś, co ją powoływało do istnienia, nadawało jej strukturę i wyznaczało zakres jej działa-

\footnotetext{
${ }^{14}$ Ujmując to w wielkim skrócie: państwo prawa oparte jest na wolności, która akceptuje konieczność istnienia nieprzekraczalnych granic. Natomiast idea demokracji, wedle której człowiek tym bardziej jest człowiekiem, im bardziej poszerza zakres swej władzy, niesie w sobie pojęcie wolności jako nieustannego procesu wyzwalania się jednostki od wszelkich ograniczeń - od tego wszystkiego, co nie zależy od niej, czego sama nie ustanowiła i czego nie jest panem. ${ }_{15}$ Por. E.W. Böckenförde: Pojęcie i problematyka państwa konstytucyjnego, w: idem: Państwo prawa w jednoczacej się Europie, przekład P. Kaczorowski, Instytut Studiów Politycznych PAN, Warszawa 2000, s. 34.
} 
nia. Zgodnie $z$ idea państwa konstytucyjnego „każdy organ władzy państwowej istnieje i funkcjonuje dopiero $\mathrm{w}$ ramach konstytucji, jest pouvoir constitué. [...] I nawet sam lud - również w przypadku państwa demokratycznego - nie włada konstytucją. Występuje on $\mathrm{w}$ porządku konstytucyjnym jako organ $z$ określonymi, wyraźnie przypisanymi mu kompetencjami, na przykład wybór reprezentacji narodu ewentualnie udział $\mathrm{w}$ referendum. Jeśli już $\mathrm{w}$ ogóle, to suwerenem jest tutaj sama konstytucja"16. Innymi słowy, koncepcja ta pomyślana jest tak, by wyeliminować pojęcie suwerenności $z$ refleksji nad państwem. Pojawia się ono tylko wtedy, gdy zadajemy pytanie o władzę konstytuująca, o to, kto może stanowić i legitymizować konstytucję. Okazuje się, że zwierzchnik - naród - wypowiada swoja wolę $\mathrm{w}$ akcie stanowienia konstytucji, przenosi na nia swe uprawnienia, potem zaś znika. Odtąd życie wspólnoty państwowej ma się toczyć pod niepodzielnymi rządami ustawy zasadniczej.

To, co przynosi ze soba idea państwa konstytucyjnego, jest więc nie tyle ubogaceniem aksjologicznej treści porządku państwowego - tę wypełnia przede wszystkim idea państwa prawa - ile raczej próba nowego sformułowania koncepcji jedności państwa i jej zwierzchniej władzy. Przekonanie, że to konstytucja staje się - od momentu jej przyjęcia - jedynym suwerenem, jest jednak fikcja. Ustawa zasadnicza to ostatecznie tylko zapis pewnego normatywnego porządku, żadna zaś norma nie ma mocy, by stosować samą siebie ${ }^{17}$. Problemu najwyższej władzy jako mocy sprawczej nie da się obejść i wyeliminować, ponieważ państwo może istnieć wyłącznie jako jedność działania, gwarantująca zewnętrzne bezpieczeństwo oraz wewnętrzny porządek i pokój społeczny. Musi w nim się znajdować ośrodek władny podejmować ostateczne decyzje, co staje się oczywiste zwłaszcza wtedy, gdy dochodzi do sporów wokół rozumienia treści konstytucji czy wręcz jej obowiązywalności.

6 Ibidem, s. 37

17 Ibidem, s. 43. 
Obecnie, w stosunku do dawnej alternatywy: monarcha - naród $^{18}$, w ramach państwa konstytucyjnego pojawia się nowy pretendent do suwerenności, powołany na mocy samej konstytucji - mianowicie sadownictwo konstytucyjne. Władza sadownicza, której nawet Monteskiusz nie uważał za władzę w ścisłym sensie, ponieważ nie stała za nią żadna samoistna siła ${ }^{19}$, staje się - jako sąd konstytucyjny - czynnikiem rozstrzygającym o najważniejszych działaniach państwa. Tym samym okazuje się rzeczywistym i konkurencyjnym wobec innych organów władzy ośrodkiem decyzji politycznych. W ramach państwa prawa musi to rodzić nowe, nieznane wcześniej problemy.

\section{II}

Na tle powyżej zarysowanych ram aksjologicznych nowoczesnego państwa prawa zasygnalizujmy najważniejsze kwestie i dylematy, które należałoby rozważyć, przystępując do prac nad konstytucja tu i teraz - w Polsce Anno Domini 2007. Chodziłoby tutaj o podejście całościowe, a nie o mniej lub bardziej istotne, szczegółowe korekty, które można by wprowadzić do obowiazującej ustawy zasadniczej, aby poprawić bieżące funkcjonowanie państwa. Niektóre $z$ podniesionych kwestii moga się wydać dość zaskakujące, ponieważ kwestionuja pojęcia i instytucje uchodzące za nienaruszalne dogmaty. Jest to, oczywiście, tylko pierwszy, wstępny szkic, wymagajacy uzupełnienia o inne istotne problemy. Daleko mu również do systematyczności, choć kolejność przedstawionych poniżej kwestii stara się zachować określony porządek.

\footnotetext{
${ }_{18}$ Ta alternatywa nie wyraża zreszta precyzyjnie istoty sporu. W czasach nowożytnych istnieli wprawdzie władcy uważający państwo za swoja prywatna własność, jednak nie brakowało i takich, którzy uznawali, że jedynym suwerenem jest naród, a pełniona przez siebie władzę postrzegali jako służbę narodowi. Spór wokół kwestii suwerenności dotyczył więc raczej tego, kto - monarcha czy parlament - ma większe prawo być uważanym za właściwego reprezentanta narodu. Jego dzisiejsza ilustracja jest rywalizacja między wizją ustroju prezydenckiego, będącego współczesną wersja monarchii, a ustrojem, w którym główną rolę odgrywa parlament.

${ }_{19}$ Por. Monteskiusz: O duchu praw, przekład T. Boy-Żeleński, Wydawnictwo Antyk, Kęty 1997, s. 140 (ks. XI, rozdz. VI).
} 
1. Aby przygotowanie i uchwalanie nowej ustawy zasadniczej miało sens, muszą zostać spełnione (a) określone warunki (moment konstytucyjny), muszą również zostać dokonane pewne (b) rozstrzygnięcia przedkonstytucyjne - poprzedzajace stanowienie konstytucji, które w istotny sposób wpływaja na kształt projektowanego porządku państwowego.

(a) Przede wszystkim musi istnieć siła polityczna, zdolna narzucić nowy porządek; musi również istnieć wizja ładu politycznego stanowiaca istotna alternatywę dla dotychczasowego status quo.

W 1997 roku taka wystarczajaca siłę, jak się okazało, miała „koalicja konstytucyjna”, która uchwaliła Konstytucję RP, natomiast ustanowiony, a raczej utrwalony wówczas porządek państwa - ze względu na to, kto go ustanowił - był i nadal jest obarczony "grzechem pierworodnym” jawnego lekceważenia zasady sprawiedliwości, co dyskwalifikuje go jako etyczna podstawę państwa ${ }^{20}$.

Obecnie uchwalenie nowej konstytucji wymaga nie tylko wystarczającej siły politycznej, ale także ostatecznego rozwiązania kwestii komunistycznej przeszłości, zgodnie $z$ bezwzględnym poszanowaniem wymagań sprawiedliwości.

(b) Sam sposób stanowienia konstytucji ma ogromy wpływ na jej ostateczny kształt. Wyznaczenie ciała przygotowującego konstytucję oraz określenie procedury jej przyjmowania nie tylko jasno pokazuje, gdzie w państwie znajduje się ośrodek suwerennej władzy, ale także wyznacza dalszy przebieg tych prac. Przekazanie zadania opracowania tekstu parlamentowi (Zgromadzeniu Narodowemu) czy też wyłonionej $z$ niego komisji konstytucyjnej - jak to było w przypadku konstytucji obowiązującej w Polsce - oznacza, że dominująca rolę w państwie odgrywa idea demokracji, zaś projektowane państwo ma zabezpieczać interesy ponadpartyjnej kasty demokratycznych polityków.

Parlament, postrzegany w duchu idei demokratycznej, w sposób naturalny aspiruje do pozycji suwerena i chce również wystapić

\footnotetext{
${ }^{20}$ Watek ten rozwijam w: Z. Stawrowski: Aksjologia i duch Konstytucji III Rzeczypospolitej, „Przeglad Sejmowy” 2007, nr 4 (81), s. 49-64.
} 
jako władza konstytuująca w akcie ufundowania porządku państwowego. $Z$ punktu widzenia natomiast organicznej wizji państwa i władzy parlament jest tylko jednym $z$ wielu elementów złożonego organizmu państwowego i nie ma powodu, by go w tej kwestii wyróżniać bardziej od innych, nie mniej koniecznych organów. Dlatego bardziej odpowiednia do stanowienia ustawy zasadniczej wydaje się raczej instytucja konstytuanty, specjalnego ciała powoływanego tylko i wyłącznie w tym jednym celu, której członkowie maja odpowiednie kompetencje oraz niekwestionowany mandat na przygotowanie tekstu konstytucji. Jej powołanie $z$ pewnościa może się przyczynić do poprawy jakości merytorycznej, a także większej zwięzłości ustawy zasadniczej w stosunku do tej, która obowiazuje obecnie. Tak przygotowana konstytucja - aby nabrać jednoczacej wspólnotę mocy - powinna zostać zatwierdzona w ogólnonarodowym referendum, przy zachowaniu zasady, że weźmie w nim udział co najmniej 50 procent (być może poprzeczkę tę należałoby nawet podnieść jeszcze wyżej!) uprawnionych do głosowania obywateli.

2. Powszechnie uznawany dziś za normę porządek państwowy przyjęło się określać mianem demokratycznego państwa prawa. Określenie to wymaga jednak wyjaśnienia $i$ istotnej modyfikacji.

(a) Państwo prawa bywa często rozumiane w duchu pozytywizmu prawniczego jako państwo prawne (por. art. 2 Konstytucji RP) - to znaczy takie, którego porządek określony jest wyłącznie przez system obowiazujących norm, nie mających żadnego innego uzasadnienia niż to, że faktycznie obowiąują. Państwo prawa, tak jak je ujmuje nowożytna tradycja filozoficzna (między innymi Kant) ma jednak głębsze znaczenie i odwołuje się - jako do swego uzasadnienia - do wartości fundamentalnych, nienaruszalnych, a więc transcendentnych wobec porzadku prawa stanowionego: godności człowieka, jego wolności, wreszcie do idei sprawiedliwości, która nie ma charakteru wyłącznie proceduralnego, lecz jest osadzona właśnie na tych podstawowych wartościach. Innymi słowy, w państwie prawnym mamy do czynienia wyłącznie 
$\mathrm{z}$ prawem pojmowanym jako lex, natomiast $\mathrm{w}$ państwie prawa (albo wyrażając to jeszcze mocniej: w państwie prawym) konkretne ustawy podlegaja ocenie również $z$ perspektywy ius.

Sam pomysł nadania państwu konstytucji, a przede wszystkim umieszczenia $\mathrm{w}$ niej kodeksu praw podstawowych, to $\mathrm{w}$ pewnym sensie próba zapisania językiem prawniczym tego, co bezwzględnie słuszne i sprawiedliwe. Konstytucja należy, co prawda, również do porządku prawa stanowionego, ale ze względu na swa formę i treść dostarcza kryteriów oceny zwykłej działalności ustawodawczej. Ocena zgodności ustawy z konstytucja przez powołany do tego organ to zinstytucjonalizowana forma moralnej oceny obowiąujacego prawa jako sprawiedliwego bąź niesprawiedliwego. Porzadek etyczny zapisany w konstytucji w stosunku do normalnie stanowionego prawa (lex) pełni rolę swego rodzaju reprezentanta ius. $Z$ tego względu zapisy konstytucyjne dotyczace podstawowych praw musza być jak najbardziej doskonałe, jak najbardziej zbliżone do naszego aktualnego - tu i teraz - wyobrażenia o sprawiedliwym państwie.

(b) Łaczenie ze soba - zarówno na poziomie idei, jak i praktyki - demokracji i państwa prawa to istotny błąd, ponieważ pozostaja one $\mathrm{w}$ zasadniczym konflikcie. Państwo prawa, w którym do głosu dochodzi zasada demokratyczna, podlega erozji etycznej, a w jego ramach wszelkie wymiary życia społecznego zostaja poddane upolityczniającej je presji. To jednak państwo prawa, nie zaś demokracja jest gwarantem poszanowania godności i wolności człowieka oraz przestrzegania sprawiedliwego porzadku. Dlatego wydaje się wskazane, by - nie zważając na poprawność polityczna - zrezygnować $z$ określenia „państwo demokratyczne”. W jego miejsce warto wprowadzić pojęcie polityczne, bardzo bliskie polskiej tradycji, odzwierciedlające te wszystkie wartości, które powszechnie, choć mylnie, przypisywane sa demokracji. Idea republiki - czyli, mówiąc po polsku: rzeczypospolitej - zawiera w sobie podobny postulat obywatelskiego zaangażowania w politykę, ale motywowany nie tyle prawem każdego do sprawowania władzy, ile postawa 
służebną wyznaczoną poczuciem odpowiedzialności za ojczyznę, rozumiana jako dobro wspólne. Rewolucja semantyczna polegająca na zastapieniu demokratycznego ustroju politycznego ustrojem republikańskim nie musi wcale pociagać za soba radykalnej rewolucji ustrojowej - niemal wszystkie instytucje uznawane za demokratyczne moga funkcjonować jako instytucje republikańskie - lecz istotne przesunięcie akcentu, co poprzez drobne zmiany instytucjonalne ${ }^{21}$ otwiera szansę zapoczątkowania stopniowej przemiany przenikającego państwo ducha.

Konkretna propozycja, streszczająca uwagi przedstawione w tym punkcie, byłby zapis, który dwa pierwsze artykuły obowiązującej obecnie konstytucji zastępowałby prostym zdaniem: „Rzeczpospolita Polska jest państwem prawa".

(c) Najważniejszą pod względem aksjologicznym częścią konstytucji, w której expressis verbis przedstawiony zostaje etyczny fundament państwa, jest katalog praw podstawowych. Wspó1cześnie główny problem stanowi inflacja owych praw, nie tylko ich zbytnie uszczegółowianie, ale również umieszczanie wśród nich postulatów politycznych, przywilejów socjalnych czy ogólnie słusznych oczekiwań. (Pouczająca ilustrację takiego podejścia stanowi II rozdział Konstytucji RP.) Te wszystkie zbędne dodatki nie tylko zaśmiecaja konstytucje, ale przyczyniają się również do dewaluacji rzeczywistych praw podstawowych, których istotne dla zachowania międzyludzkiego porządku znaczenie rozmywa się $\mathrm{w}$ zalewie dołaczonych do nich quasi-praw.

Karta praw podstawowych musi zawierać dwie - wymienione wyżej - konstytutywne dla państwa prawa zasady:

- poszanowania nienaruszalności przestrzeni prywatnej, to znaczy życia, nienaruszalności cielesnej, własności prywatnej, a także prywatności rodziny;

\footnotetext{
${ }^{21}$ Wskażmy przykład instytucjonalnego wyrazu różnicy między podejściem demokratycznym a republikańskim: o ile immunitet poselski - i to rozumiany maksymalnie szeroko - pozostaje $\mathrm{w}$ pełnej zgodzie $\mathrm{z}$ idea demokratyczna, o tyle $\mathrm{w}$ państwie o ustroju republikańskim poseł czy urzędnik państwowy, który dokonałby przestępstwa, zostałby za swój czyn ukarany znacznie surowiej niż zwykły obywatel, i to tym surowiej, im wyższe piastuje stanowisko.
} 
- swobody działania w przestrzeni publicznej, ograniczonej jedynie taka sama swoboda innych jednostek (lub społeczności) ${ }^{22}$.

Wyliczanie owych praw w konstytucji mogłoby się w gruncie rzeczy na nich zakończyć. Dla wymiaru sprawiedliwości - który zajmowałaby się tym, co zgodnie $z$ nazwa do niego należy- taki zapis stanowiłby wystarczajaca podstawę działania. Reszta mogłaby się znaleźć w stosownych kodeksach. Oczywista zaleta takiego rozwiazania jest jego prostota. Za precyzowaniem, konkretyzowaniem i uszczegóławianiem praw podstawowych może natomiast przemawiać sytuacja kraju, w którym przez wiele lat prawa te były fikcja, i nadal przez wielu - w tym także urzędników państwowych - traktowane sa nie jako osobiste uprawnienie, ale jako coś, co przysługuje obywatelom $z$ łaski państwa. Pytanie, czy i jak dalece prawa podstawowe należy dalej konkretyzować, pozostaje kwestią otwarta.

Innym argumentem przemawiajacym na rzecz precyzowania podstawowych praw jest obecna sytuacja „wojny cywilizacyjnej”, która toczy się wewnątrz kultury zachodniej, gdy pojęciom dotychczas rozumianym jednoznacznie nadawany jest nowy sens. Jasne określenie „prawo do życia” nie wystarcza już dziś, by chronić życie każdego człowieka; podobnie oczywista jeszcze niedawno instytucję małżeństwa, aby nie było żadnych wątpliwości, trzeba obecnie dookreślać jako „Związek kobiety i mężczyzny”.

W kontekście „wojny cywilizacyjnej” niezbędne jest również pozytywne zdefiniowanie wolności religijnej jako „wolności do religii” - jako swobody publicznego wyrażania swoich przekonań religijnych, ograniczonej jedynie ogólnymi zasadami państwa prawa. Warto $\mathrm{w}$ tym miejscu podkreślić, że wolność religijna nie jest niczym innym niż najwyższym przejawem swobody działania - jest swobo-

\footnotetext{
${ }^{22}$ Zasadę wolności (swobody) działania w sferze publicznej można dookreślić, wyróżniając trzy najistotniejsze wymiary aktywności ludzkiej: (a) swoboda zawierania umów oraz tworzenia stowarzyszeń pod warunkiem pełnego respektowania ich dobrowolności - sfera społeczeństwa obywatelskiego, w tym przede wszystkim działalności gospodarczej; (b) wolność religijna, czyli swoboda publicznego działania wszelkich wspólnot religijnych (etycznych), których etos jest do pogodzenia $z$ moralna zasada państwa - sfera etyczno-religijna; (c) swoboda podejmowania działalności politycznej oraz tworzenia stowarzyszeń politycznych - sfera polityczna.
} 
da podejmowania takich działań, które osoba uważa dla siebie za najistotniejsze, bo dotyczace tego, co uznaje za najwyższe dobro.

Być może, w kontekście postępującej integracji europejskiej, warto byłoby - za przykładem Francji i jej nienaruszalnej zasady „świeckości państwa” - wprowadzić swojego rodzaju konstytucyjny hard core - zestaw praw podstawowych, których sformułowania nie podlegałyby już żadnym zmianom i żadnym negocjacjom międzynarodowym.

W wykazie praw podstawowych istotne jest również jasne odróżnienie praw człowieka od praw obywatelskich (w tym przede wszystkim praw politycznych), to znaczy takich, które należą się człowiekowi niejako $z$ natury, $z$ tego tylko powodu, że jest człowiekiem, od takich, których źródłem jest przynależność do określonej wspólnoty politycznej, co $z$ drugiej strony pociaga za sobą także konkretne obowiąki wobec tej wspólnoty. Ważne jest również, by jednoznacznie wskazać, że te pierwsze prawa, których źródłem jest przyrodzona godność osoby, mają wyższą range niż te drugie. Zapis taki rozstrzyga, że wspólnota polityczna będzie rozumiana i zorganizowana jako państwo prawa, nie zaś jako demokracja.

4. W kwestiach związanych $z$ organizacja ustroju politycznego należy przede wszystkim zwrócić uwage na to, że mamy do czynienia nie tyle $z$ zestawem izolowanych od siebie instytucji, które można dowolnie i niezależnie od siebie zmieniać, reformować lub likwidować (na przykład propozycje zniesienia Senatu), ile właśnie $z$ jednym organizmem politycznym, w którym poszczególne organy władzy pełnią uzupełniające się funkcje i każda zmiana jednego $z$ nich wpływa istotnie na funkcjonowanie pozostałych. Potrzebne jest więc spojrzenie całościowe.

Wiąże się $z$ tym również konieczność porzucenia dogmatu o trójpodziale i równoważeniu się władz (por. art. 10 Konstytucji $\mathrm{RP})$, który fałszuje rzeczywisty obraz relacji ustrojowych - jest, po pierwsze, pusta deklaracja, $z$ której niewiele wynika ${ }^{23}$; po wtóre,

${ }^{23}$ Najbardziej konsekwentna próbą realizacji tej zasady była konstytucja amerykańska. W państwach europejskich, gdzie rząd stanowi emanacje parlamentu, jedność oraz przenikanie się 
traktuje władze nie jako istotne funkcje państwa, z których każda ma odrębna, istotna specyfikę, lecz jako konkurujące ze soba ośrodki suwerennej władzy, co wręcz rozbija jedność państwa.

(a) Podstawową sprawą dla tej jedności jest rozstrzygnięcie, gdzie ma leżeć punkt centralny państwa, ośrodek władzy zwierzchniej, stanowiący jądro suwerenności państwowej i reprezentujący naród jako właściwego suwerena - ośrodek, w którym kształtuje się wola polityczna i z którego ona wychodzi w postaci ostatecznych decyzji, wiążących wszystkich obywateli i wszystkie organy państwa.

Teoretycznie możliwe sa tu dwa rozwiazania:

- albo będzie to parlament, co odpowiada wizji demokratycznej ${ }^{24}$;

- albo będzie to prezydent (współczesny odpowiednik monarchy), co odpowiada organicznej wizji wspólnoty państwowej.

Natomiast wszelkie przejawy suwerenności, które wykazuja inne instytucje państwowe (na przykład kompetencje zwierzchnie przysługujace premierowi w systemie kanclerskim czy możliwość podejmowania ostatecznych rozstrzygnięć przez sadownictwo konstytucyjne) muszą znajdować swoje źródło i legitymację w jednej $z$ dwóch wyżej wymienionych form reprezentacji narodu.

(b) Władza wykonawcza, na co wskazuje jej nazwa, nie jest wcale władzą najwyższą, lecz instytucja pochodna, której zadanie polega na wykonywaniu decyzji władzy zwierzchniej. Jej właściwa funkcja polega na rządzeniu lub, mówiąc precyzyjniej, zarządzaniu bieżącymi sprawami państwa zgodnie $z$ ogólnymi wytycznymi przedstawionymi przez władze zwierzchnią. Oczywistym zadaniem władzy wykonawczej jest również gwarantowanie i egzekwowanie decyzji podejmowanych przez wymiar sprawiedliwości, ponieważ jego sprawne i skuteczne funkcjonowanie stanowi warunek sine qua non istnienia państwa jako stanu bezpieczeństwa i pokoju,

władzy ustawodawczej i wykonawczej, mimo konstytucyjnych deklaracji o ich odrębności i przeciwstawności, jest oczywista.

${ }^{24}$ Jeszcze bardziej demokratyczna - bo bezpośrednia - formą sprawowania władzy suwerennej przez naród są referenda. Na tej zasadzie oparty jest ustrój polityczny Szwajcarii. 
a jako takie wchodzi w zakres podstawowych obowiąków każdej władzy zwierzchniej stojącej na straży jedności państwa.

Organizacja władzy wykonawczej jest uzależniona od tego, gdzie mieści się ośrodek suwerennej władzy. Może to być rząd $z$ premierem na czele, wyłaniany przez parlament, albo też rząd powoływany przez prezydenta i jemu podporzadkowany.

(c) Władza ustawodawcza utożsamiana bywa powszechnie $z$ parlamentem, co jest słuszne tylko wtedy, gdy podziela się demokratyczne rozumienie państwa. Historycznie rzecz biorąc, funkcje ustawodawcze były przez długi czas wyłączna prerogatywa monarchy jako władzy suwerennej, a pierwsze powstajace parlamenty nie miały stanowić praw, lecz wyrażać zgodę na stanowienie podatków.

Instytucja parlamentu pełni obecnie przynajmniej trzy istotnie różne funkcje. Parlament to:

- forum dyskusji ${ }^{25}$ nad sprawami państwa i ośrodek kształtowania się jednej woli politycznej - tu przejawia się element suwerenności, najwyższej władzy w demokratycznie rozumianym państwie;

- miejsce ścierania się interesów (uchwalanie budżetu i podatków);

- izba ustawodawcza w ścisłym sensie.

Na tle tych funkcji bardziej klarowny staje się problem podziału parlamentu na różne izby.

Zgodnie $z$ tradycją demokratyczna - w której parlament jako jedyna prawomocna reprezentacja całego narodu jest wyłącznym ośrodkiem władzy suwerennej, a tym samym pełni funkcję ustawodawczą i wyłania $z$ siebie rząd - druga izba okazuje się w sposób oczywisty zbędna.

Ta druga izba, czyli senat, to - historycznie rzecz biorac - izba arystokratyczna, reprezentująca nie tyle cały naród, ile jego „lepszą" czy też „szlachetniejszą" część. Dlatego też przypisywano jej szczególna „moderacyjna” funkcję - wprowadzania do państwa

${ }^{25} \mathrm{Na}$ tę właśnie funkcję wskazuje etymologia słowa „parlament”. 
elementów umiarkowania. Senat miał być przede wszystkim izba namysłu i refleksji nad sprawami państwa. Wraz $z$ powstaniem Stanów Zjednoczonych pojawiła się również inna koncepcja senatu, zwiazana $z$ federacyjnym modelem państwa ${ }^{26}$.

Gdyby zachować intuicję, która kryje się za rozumieniem senatu jako izby „lepszych" - oczywiście nie w sensie, jak to ongiś bywało, lepszego pochodzenia czy większego majattku, ale jako posiadanie lepszych kompetencji, wiedzy czy zasług wobec państwa - oraz stosownie do tego zaprojektować jego kształt, funkcje i sposób powoływania, instytucja ta mogłaby pełnić ważną rolę $\mathrm{w}$ organizmie państwowym - właśnie namysłu, refleksji i rozsądku. Być może to właśnie senatowi powinna przypaść główna rola w ściśle prawodawczej funkcji państwa, sejmowi zaś można by pozostawić dwie pierwsze funkcje, które spełnia parlament.

(d) Oddzielna kwestią pozostaje władza sądownicza, o której - jako o władzy politycznej - można mówić dopiero w momencie pojawienia się sądownictwa konstytucyjnego. Wcześniej sądy przypisane były władzy suwerennej - sędziowie byli urzędnikami, którzy sądzili w imieniu monarchy, ten zaś nie tylko pozostawał ostateczna instancją wymiaru sprawiedliwości, ale nawet stał ponad tym porzadkiem - przejawem tego jest istniejąca do dziś instytucja prawa łaski. Pojawienie się sądownictwa konstytucyjnego, które może wpływać na kształt ustawodawstwa zwykłego (wkraczając w jakimś stopniu w kompetencje władzy ustawodawczej), na sposób rozumienia relacji między poszczególnymi władzami, a także, co najistotniejsze, określać poprzez wykładnię konstytucji, komu przysługuje zwierzchnia władza, jest dzisiaj, jak się zdaje, największym wyzwaniem teoretycznym i praktycznym dla refleksji nad państwem ${ }^{27}$.

\footnotetext{
${ }^{26}$ Gdy w 1787 roku w czasie Konwencji Filadelfijskiej zaproponowano wizję izby, która w ramach państwa federacyjnego miała stanowić reprezentacje poszczególnych stanów, poważnie dyskutowano nad pomysłem, aby była to izba trzecia, obok Kongresu i tradycyjnie rozumianego Senatu.

${ }^{27}$ Instytucja trybunału konstytucyjnego, pełniąca funkcje „strażnika konstytucji”, bardzo przypomina Platoński pomysł „strażników praw”, którzy w swym osądzie istniejących praw i instytucji mają się kierować wyłącznie doświadczeniem i rozumem.
} 